Оригинални научни рад

УДК 821.163.3.09-1

Примљен: 24. марта 2021.

Прихваћен: 19. априла 2021.

Милена М. Станковић ${ }^{1}$

https://doi.org/10.46630/phm.13.2021.25

Универзитет у Нишу

Филозофски факултет

Департман за србистику

\title{
LIHNIDOS ИЛИ ГРАД КОЈИ СВЕТЛИ НА ГОРИ
}

У овом раду бавимо се поетиком топоса града Охрида у македонској поезији 20. века. Неке од најзначајнијих одлика књижевног топоса Охрида у македонском песничком дискурсу прошлог века, тумачићемо на корпусу одабраних текстова: Св. Наум Михаила Рениова (1936), Охрид Христа Попсимова (1916-1989), Охридска куќа Љиљане Чаловске (1920-1997), Самуилова тврдина Србе Ивановског (1928-2014), Во ирквата Свети Климент Љупчета Стојменског (1931-2007) и Наши фрески Милована Стефановског (1952). Песничке текстове посматраћемо у контексту библијске симболике и Јунгове теорије архетипова и колективно несвесног, уз позивање на теорију хијерофаније Мирча Елијадеа.

Кључне речи: Охрид, Јунг, архетип, Центар Света, симбол, светлост, камен

1. Охрид као Елијадеов архетип Центра Света

„Той ги хранел по този начин със словото, което е истински хляб и укрепва действително сърцата.“ (Теофилакт Охридски Житије Св. Климента Охридског)

Симболика Охрида као прапочетка Света једна је од његових најважнијих одлика у модерној песничкој географији. Мотивом града Охрида као прапостојбине свеколиког живота, започиње једна од познатих македонских песама 20. века, Свети Наум, аутора Михајла Ренџова: „Тука је почетокот на светот / И зачетокот на животот: / На билијето и тварта / На водата и жарта / Создадени со божја / Благодат.“ (RENDŽOV 2016: 128) ${ }^{2}$ Књижевна слика Охрида као прапочетка, утемељена је на древном космогонијском мотиву о стварању Космоса (грч.

1 milenastankovic1705@hotmail.com

2 Сви текстови песама цитирани према: Дојди во Охрид: Антологија на песни за Охрид, приредили Димитар Пандев, Славе Ђорђо Димоски, предговор Димитар Пандев, Охрид: Графоден, 2016. 
Ко́бно - свет, васиона), хармоније, лепоте и реда из првобитног хаоса (грч. Ха́оৎ - празнина, бездан), нереда и конфузије. Град Охрид, као „почеткот на светот“, јасно асоцира на архетип Центра Света који Мирча Елијаде у познатој књизи Свето и профано дефинише као „пупак света“, ембрион живота: „Универзум се рађа из Центра, он се шири из једне централне тачке која је исто што и 'пупак' код човека. Према Rig Vedi (X, 149) Универзум се тако родио и развио: почев од једног језгра, из једне централне тачке.“ (ELIJADE 2003: 92)

Симболичка пројекција града Охрида као архетипа прапочетка дубоко је уткана у дугу књижевно-филозофску традицију тумачења мистерије о настанку света. Покушаје да се откључа древна загонетка проналазимо у метафорама митолошких наратива (нпр. „creatio ex nihilo ram. „стварање ни из чега” у античкој митологији и др.), у филозофским списима старих мислилаца (Аристотела, Платона, Хераклита, Августина и др.), као и модерним научно-космогонијским истраживањима (Лематреова теорија прајезгра, Кантова, Хублеова, Линдова, Ајнштајнова теорија релативитета и др). (TADIĆ 1996: 122) Миленијумско истраживање прајезгра и праматерије из које је све поникло, континуирано прати идеја о примордијалном хаосу/конфузији из којег је настао уређени систем, космос/живот. (TADIĆ 1996: 122) Још код Хесиода проналазимо идеју о Хаосу као прапочетку који није представљао обичан бездан и празнину. За Платона Хаос представља конфузан простор, без реда и хармоније, у коме је појава демијурга унела принцип закона и поретка. Хаос је у Платоновој филозофији слика света без присуства Бога, разума, мудрости и канона. (TADIĆ 1996: 121) Идеју о стању хаоса/мрака/безобличног које претходи појави света и живота, проналазимо и у првој глави новозаветног Јеванђељь по Јовану:

„У почетку беше Реч, и Реч беше у Бога, и Бог беше Реч. /Она беше у почетку у Бога. / Све је кроз Њу постало, и без Ње ништа није постало што је постало. / У Њој беше живот, и живот беше видело људима. / И Видело се светли у тами, и тама Га не обузе. / Посла Бог човека по имену Јована. / Овај дође за сведочанство да сведочи за Видело да сви верују кроза њ. / Он не беше Видело, него да сведочи за Видело. / Беше Видело истинито које обасјава сваког човека који долази на свет.“ (Јн 1: 1-7)

Према новозаветној филозофији, интеревенцијом Логоса/Божије Речи/Исуса Христа из хаоса, конфузије и бездана, настаје космос, свет, видело и разум. (С̌ASNI 2015: 186-187) Филозофски појам Логоса у најстаријем периоду своје егзистенције, од Хомера до новозаветне догме, имао је два основна значења: „riječ, govor, gramatički iskaz, svojstvo, istina, slava (kvaliteta) red volja“, као и „razum, ljudski pojam, um, učenje, istinito učenje, zakon (mjera), postupak." (DONAT 1989: 192) 
На филозофском значењу Логоса као Речи/Ума/Учења/Закона, Ренџов у својој песми гради топос Охрида, као најстаријег средњовековног центра словенске културе: „Оттука извира и блика / Светлината и СЛОВО.“ (RENDŽOV 2016: 121) Посебно је сугестивна Ренџова употреба архаичне, старословенске речи слово. Као пандан појму Логоса, односно,

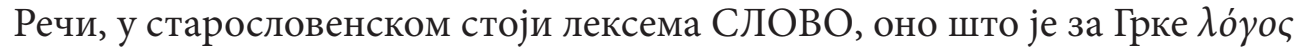
(= Логос), за Словене је слово или реч путем које су први пут „угледали“ светлост бог-о-са-знања. Мотив светлости која у Ренџовој песми Свети Наум доноси Логос/Слово асоцира, на богоспознају и покрштење, али и на просвећење и описмењавање, који су донели лучу раз-ума и духовног рођења. „Тука е запишано / Со ведски резби / Божјето и небесното / Старото и новото.“ (RENDŽOV 2016: 121) Ту, у Слову, старословенском Логосу, који симболизује први језик и прво писмо, створен је праоблик културног, језичког, религијског и књижевног идентитета читаве породице словенских народа. Наум Охридски је божанском речју словенско племе из мрака паганства и варварства превео у светлост племенитог и култивисаног хришћанског народа. Овакав процес сакрализовања и уређивања једног аморфног и аветињског простора (Хаоса), М. Елијаде тумачи као симболичко понављање божанске космогоније. „Ораганизујући један простор понавља се дело богова, које служи као модел.“ (ELIJADE 2003: 84)

У песми Охрид Христо Попсимов као пандан носиоцу божанске луче, јеванђељисти Јовану, поставља Св. Климента Охридског који је на обале Охридског/Лихнидског језера из Велике Моравске донео древне литургијске свитке исписане старословенским језиком и глагољичним писмом: „И Климент од тука го озари векот, со бесмртен луч светна в темната доба. / три илјади души поминаја по пат / со хоругви златни и новите книги.“ (POPSIMOV 2016: 39) Стих/мисао о три хиљаде душа које су разнеле златне и нове књиге, проистиче из палимпсеста, тј. древног Житија св. Климента Охридског у коме охридски архиепископ Теофилакт први записује предање о три хиљаде ученика, лучоноша, који су изникли из Климентовог културно-књижевног центра и наставили да разносе светлост знања, којим и данас словенски народи зраче.

\section{Lichnidos или град који на гори светли}

„Не може се сакрити град који лежи на брду.“

(Jм 5: 14)

Слика Охрида као прајезгра из којег је Бог створио Свет (архетип Центра Света), имплицира идеју о граду Охриду (Лихнидосу) као песничком пандану библијском граду Сиону: „Најсветији је створио свет 
као ембрион. Као и ембрион, на исти начин је Бог отпочео стварање из пупка, а овај се затим одатле проширио у свим правцима. А пупак Земље, Центар Света, јесте Света Земља. Үота тврди: 'Стварање Света отпочело је на Сиону.“ (ELIJADE 2003: 92) Идеју о песничкој сродности града Охрида са библијским градом Сионом, у овом раду тумачићемо на примерима текстова Света Собија Михаила Ренџова и Охридска куќа Љиљане Чаловске.

Сион (hebr. zijjon) представља највиши југозападни брег Јерусалима. (VUJAKLIJA 1980: 1033) Најпре је представљао тврђаву смештену на брду, по којој је касније и читав град добио назив Брдо Сион (BIHALJI MERIN 1986: 879). Сионску тврђаву је освојио библијски краљ Давид, по коме је град у Светом писму и називан Давидов град. „Сион је значајан у пророчанској и богослужбеној књижевности и ту значи: Божији град (Пс 48, 2; Јер 31, 6). Јахвеов град (2 Мој 30, 14), Свето брдо (Пс 2, 6), Божије пребивалиште (Пс 9, 12).“ (RAKIĆ 1994: 192) У Библији се топос града јавља као представа самог Бога/творитетеља, Imago Dei, а сам процес изградње града неретко подразумева духовну изградњу човека по узору на слику Бога, односно, уздизање и обожење људске душе: „У Богу је спасење моје и слава моја, / тврди град и пристаниште / мени је у Богу.“ (Пс 62, 7)

Јасно је да се у Библији град Сион не своди само на референцијално значење. „Са Сиона Бог се објављује (Ам 1, 2), шаље помоћ и даје благослов (Пс 128,$5 ; 134,3)$. У Новом завету схвата се као место искупљених људи (Јев 12, 22) и слика коначног спасења (Откр 14, 1).“ (RAKIĆ 1994: 193) У корпусу библијских текстова, град Сион се фигуративно односи на цркву, односно на заједницу верника коју она окупља. (VUJAKLIJA 1980: 1033) Ширећи значење на цркву и њену паству, Сион је почео симболично да означава и сам израиљски народ, као изабрани народ од Бога. (BIHALJI MERIN 1986: 879) Такође, Сион/Давидов/Божји град у јудеохришћанској религији представља симболичан назив за Јерусалим и јеврејску државу, односно за изгубљену домовину. (BIHALJI MERIN 1986: 879)

У истраживању симболичких веза између града Охрида и града Сиона почећемо од мотива града који етеричном светлошћу светли на гори. У песми Михаила Ренџова Св. Софија град Охрид је представљен као град светлости и лепоте: „Тука има / Толку светлина / од која јас, со жед / Посакав да / Живеам. / Тука има Толку убавина / О која јас, од убост / Можев / Да / Изгора.“ (RENDŽOV 2016: 125) Светлост, блештавило и сјај посебно су значајни за град Охрид. Древни, антички назив града Охрида гласи Лихнид/Лихнидос и семантички се повезује са лексемама светлост и блештавило: „Но уште повеќе е омилено толкувањето кое името на градот Lihnidos го поврзува со зборовите кои ги објаснуваат особеностите 
на езерото, во први ред како 'блескаво, 'сјајно' и заслепувајки 'бело' езеро, од што произлегува зборот lychnios (светилка).“ (KUZMAN 2010: 50)

Попут Сиона, и средњовековни град Охрид је представљао утврђење смештено на брду. Данашњи назив града - Охрид, према највећем броју истраживача старословенског је порекла и означава град и језеро који су смештени на брду (Охрид - град подигнут на висорвни, на хридима). (PANOV 1985: 660-667) Планина (гора) према Елијадеу представља Центар Света, свету тачку у којој се додирују све димензије. Планина „повезује Земљу и Небо, она у извесном смислу додирује Небо и означава највишу тачку Света; из чега произилази да је територија која је окружује и која чини 'наш свет', сматрана за највишу на Земљи.“ (ELIJADE 2003: 88) Не заборавимо да планина према Јунгу означава „uspon, naročito, mističan (= duhovan) uspon do vrha, odnosno u blizini Boga i mesta otkrovenja." (JUNG 1996: 180) Слика средњовековног Охрида који обасјан сунцем и Белим језером светли на гори, неумољиво подсећа на библијски град из чувене Исусове проповоди на гори Сион: „Ви сте светлост света. Не може се сакрити град који лежи на брду. Нити се пали светиљка и ставља под мерицу, него на свећњак, и светли свима у кући. Тако нека засветли ваша светлост пред људима, да виде ваша добра дела и прославе Оца вашега који је на небесима.“ (Јм 5: 14-16) Та светлост и код Ренџова и у Библији нуминозне је природе, и односи се на само присуство Бога, односно, на мудрост, учење, (раз)ум и унутарње савршенство које доносе вера и просвећење изникло из вере. Приказан кроз доживаљај блештавила и сјаја, Охрид постаје потпуно дематеријализован и претвора се у дух, мисао, лепоту харомоније и склада, у саму Imago Dei.

Попут града Сиона, који симболизује (потлачен и невин) израиљски народ и Јерусалим као израиљску отаџбину, и град Охрид се у македонској поезији јавља као симбол „татковине“, македонског народа и његове прошлости. У симболичком плетиву песме Охридска куќа Чаловска за централни мотив узима тзв. староградску охридску кућу из 19. века, која је специфичном архитектоником и стилом у многоме допринела изградњи јединствене морфологије старог градског језгра Охрида. Староградска охридска кућа је пре свега препознатљива по беспрекорној белини зидова, која у блештавој атмосфери сунчевих зрака и Лихнидског језера, оставља живописан утисак. Са културном прошлошћу македонског народа, поред мотива староградске охридске архитектуре, кућу коју Чаловска у песми „зида“ везује и симболично лајтмотивско понављање белог лабуда: „куќа (како) лебед / лебди/ врз седеф.“ (С̌ALOVSKA 2016: 137) Бели лабуд у митолошком систему Јужних Словена представља инкарнацију душе предака, те стога његово присуство увек наслућује близину оностраног које је далеко а опет дубоко укорењено у бићу. Но, на- 
ционална традиција није једини стуб на коме Чаловска гради охридску/ македонску кућу. Симболичним опекама Чаловска македонску кућу зида на полугама Божијих закона, указујући на македонски народ као на дубоковерујући народ. Другим речима, охридска кућа симболизује отаџбину македонског народа чији темељи нису постављени у земљи и калу, већ у религији, Богу и културној прошлости Македонаца. Таква визија небеске куће утемељене у Богу имплицира паралелу између македонског народа (житеља охридске куће) и израељског народа који је, протеран и изгнан, почео да гради вечни дом саздан у/на Богу.

Иначе, симболика охридске куће као божанског дома у тексту се препознаје на више нивоа. Охридска кућа је у потпуности дематеријализована и ослобођена свих просторно-временских маркера и њиховог каузалитета, те неограничена и обесконачена јасно асоцира на здање нуминозне, етеричне и божанске природе. У својој прозрачности, белини и бесконачности охридска кућа оставља утисак уздигнуте куће која стоји између неба/Бога и земље/традиције. Слика куће која попут белог лабуда лебди у неком међупростору као да тихо шаље поруку, да се ту, између неба (које високо) и земље (која је хладна) вековима ткала судбина македонског народа. Идеју о голготи поробљеног народа, снажно асоцира симболички мотив незаштићене, невино беле куће Македонаца: „белолика / белограда / стои без ограда ветру спроти.“ (ČALOVSKA 2016: 137) Белолика и белограда охридска кућа која без ограде стоји насупрот ветру, симболично представља македонску кућу / "татковину“ коју македонски народ вековима гради на раскрсници и ветрометини, одоловајући разним ветровима и претањама. Међутим, та кућа, иако незаштићена и неограђена, небеског је темеља, она је духовни храм који се зида у бићу/ срцу/уму, и ту мисаону и вољену кућу/отаџбину не може разорити ниједан ураган.

3. Град Охрид као симбол камена или Охрид као камен македонског народа

„Proučavanjem filozofa čovjek stječe sposobnost za pronalazak kamena. A kamen je opet čovjek." (Jung, Psihologija i alhemija)

„Rabbi ben Gorion је говорио за стену у Јерусалиму да се она зове Камен основе Земље, то јест, Центар Земље, јер се одатле развила целокупна Земља." (ELIJADE 2003: 93) Као што Сион представља камен Земље, тако Охрид представља камен македонског народа. Симболика камена има дугу традицију, јавља се у свим митолошким и религијским системима, те није чудо што на његовом значењском капиталу многи 
уметници граде поетику својих дела. Камен је још у најстаријим временима представљао свети предмет, зато што су „душе мртвих ('предака') оваплоћене у њему“, зато што „манифестује или представља свету снагу, божанство“, „зато што се свечани пакт или договор“десио крај њега или у њему сл. (ELIJADE 2016: 6) У Првој посланици апостола Петра (2, 4-7) камен означава самог Христа, али и вернике који се попут опека уграђују у цркву/Бога.

На примеру наших песама мотив камена асоцијативно се везују за тврђаву (Србо Ивановски, Самуилова тврдина), за православни храм/фреске (Милован Стефановски Стари фрески, Љупчо Стојменски Во ирквата Свети Климент) и камену стену (Христо Попсимов, Охрид). У књижевној географији Самуилова тврђава и храм посвећен Клименту Охридском, свецу-заштитнику града, представљају два основна амблема Охрида, на којима се гради његов препознатљив литерарни и историографски лик. Као што је познато, за Климента Охридског и средњовековни Охрид везују се почеци религијског, књижевног и културног идентитета македонског народа, због чега у песничком дискурсу Климент постаје праслика, праобразац великог мудраца, националног Учитеља и духовног водича. Климентов храм у Охриду инкарнира самог охридског патрона, и путем симболичних слика и облика савременог човека повезује са коренима његовог дела. С друге стране, цар Самуил, оснивач чувеног Самуиловог царства, чији се државни и црквени центар у македонској науци везује за град Охрид, представља архетип ратника, државног вође, док Самуилова тврђава у Охриду, бедем неосвојивог царства, постаје праобразац моћног македонског народа и његове државе. Стога, камен (свети храм, тврђава), у коме је древни охридски градитељ урезао праслике, праоблике и праречи, у македонској поезији 20. века симболично представља град Охрид као централни архетип на коме је изграђен религијски и национални идентитет македонског етноса. Симболику камена у коме је уписана културно-историјска прошлост Охрида, тумачићемо у контексту Јунговог тумачења колективно несвесног и архетипова, као и односа психоанализе и религије.

У познатој реинтерпретацији Фројдовог концепта људске психе, Јунг уводи два нивоа несвесног, онај плићи, лично несвесно, које је већ било у свесном али је заборављено или потиснуто, и колективно несвесно, које представља најдубљи и најтамнији, централни део личности. У књизи Архетипови и колективно несвесно, Јунг на следећи начин дефинише централни појам своје психоанализе, колективно несвесно: „Odabrao sam izraz 'kolektivno' jer ovo nesvesno nije individualno, već opšte prirode, što znači da ono, nasuprot ličnoj psihi, ima sadržaje i vidove ponašanja koji su svuda i kod svih individua, cum grano salis isti. Drugim rečima, ono je kod 
svih ljudi, samom sebi identično i time čini jednu, u svakom prisutnu opštu duševnu osnovu nadlične prirode." (JUNG 2003: 13) За разлику од лично несвесног које припада интимној, индивидуалној прошлости, колективно несвесно је наслеђено и припада читавом човечанству без обзира на све међусобне разлике. Садржаје колективно несвесног према Јунгу чине тзв. архетипови (archetypus).

„Јунг је сматрао да су од постанка света сви људи имали одређене доживљаје у вези са рођењем, смрћу, моћи, добрим фигурама, фигурама мајке и оца, земљом, енергијом, поновним рођењем итд. И да таква историјска универзална искуства стварају архетипове (архе-тип: праузор, праслика) као садржаје или структуралне и динамичке компоненте колективно несвесног, примарног процеса у психи човека. То су примордијалне (првобитне, прапочетне) представе или слике, које су помоћу интроспекције спознатљиви облици априористичке психичке уређености.“ (ZLATANOVIĆ 2001: 32)

Архетип је сам по себи невидљив и несазнатљив, али су његове манифестације многобројне и разнолике и могу се опажати. Архетипови се јављају замаскирани, кроз денотативни језик културних творевина - мит, бајку, религију, али и у сновима или визијима и сл. Из мноштва архетипова, Јунг издваја четири основна типа Персону, Сенку, Аниму/ Анимуса и Сопство, које у Јунговој психоанализи представља исто што и Јаство, Себство и личност. Током процеса индивидуације личност се сусреће са Персоном, Сенком и Анимом/Анимусом док не дође до самог средишта личности, до Сопства. „Ро Jungu Sopstvo/Jastvo je arhetip celine, duševnog sklada i potpunosti. Ovaj arhetip predstavlja istinsko središte celokupne, svesne i nesvesne ličnosti, a ispoljava se kroz drevne mitološke i religiozne simbolike kao što su mandela, kamen, četvorougaonost, biser, zlato, cvet i Sunce." (TREBEŠJANIN 2006: 106-107)

Камен у јунговској психоанализи представља један од значајнијих симбола Сопства (Јаства). Следствено томе, камен обухвата оно површинско, свесно (его) али и оно најдубље и најстарије, несвесно (лично и колективно). Камен је симбол целине, апсолута, савршенства, он је за Јунга, у ствари, сам - човек. У књизи Аион, Јунг значење камена везује за колективно несвесно, за темељ и средиште људске психе: „Ali on nije nikakav ljudski Ego, već jedno kolektivno biće, jedna kolektivna duša poput indijskog Hiranyagrbha, 'zlatne klice'“. Kamen je 'otac-majka' metala, jedan hermafrodit. On jeste, doduše, poslednje jedinstvo, ali ne elementarno već nastalo i složeno." (JUNG 1996: 215) У познатом делу Психологија и алхемuja, Јунг истиче да камен означава оно најдубље скривено у човеку које филозофским промишљањем покушава да спозна. Камен представља саму супстанцу психе којој човек исконски тежи, јер тек њеном спознајом, 
може овладати Соством, односно, својом целином: "Proučavanjem filozofa čovjek stječe sposobnost za pronalazak kamena. A kamen je opet čovjek. Tako uzvikuje Dorn: 'Prometnite se od mrtvih kamena u žive filozofske kamenove!' i time najjasnije izrazuje istovjetnost onoga što je skriveno u čovjeku s onim što je skriveno u kamenu." (JUNG 1984: 280)

Песничка слика камена у текстовима наших песама своје примарно значење остварује у контексту Јунгове дефиниције камена као симбола самог човека и његовог колективно несвесног. У овим песмама све је пролазно, таштина, подложно пропадању и нестајању; све осим камена. Нестала су славна средњовековна краљевства и неосвојива војна утврђења, али је на рушевинама прохујалог света једино остао камен, симбол сржи, „кичмене мождине“ сваког човека у коме неугасивим пламом живе праслике духовних Учитеља, мудраца, предака - ратника и епских тријумфа који су стварали домовину и њену част.

У песмама Охрид Христа Попсимова и Самуилова тврдина Срба Ивановског, мотив камена се везује за историјску фигуру цара Самуила. У песми Попсимов Самуила представља као седокосог жреца, који усамљен у сузама, у камену стену као у летопис вечни, уписује неизбрисиве трагове славних битки: „И цар Самуил потем славните битки / ко белокос жрец в солзи самотен умре, во летопис вечен, на камена стена / тој траги од борба невидена остај.“ (POPSIMOV 2016: 39) Представљен као свештеник, Самуил у овој сцени више подсећа на библијског Мојсија који је на Светој гори, као архетипску форму савршеног човека, записао свете божије заповести. „Заповести“ које је цар Самуил урезао у камену стену, представља јунговско колективно несвесно, универзални темељ и архаично искуство предака које сваки појединац дубоко у себи носи. Цар Самуил је свом народу урезао у камен вечни праобрасце јунаштва, љубави према отаџбини, оданости домовини, антејску повезаност са тлом и пожртвовану борбу за слободу заједнице. У песми се дубока охридска прошлост изједначује са значењем камена, односно са колективно наслеђујућим искуством, те се дијалог лирског субјекта са историјом Охрида, претвара у филозофско (само)разматрање песничког „ја“ и потрагу за самим собом. Значењска идентификација древне охридске прошлости са каменом, јасније се очитава у последњим стиховима песме: „Столетија течет во тихите ношти, / ти, вечен си, шумиш во тајното време!“ (POPARSOV 2016: 39) Векови пролазе, генерације се смењују, али потпуно исте архетипске слике „зашуме“ у сваком појединцу, враћајући га на прапочетак, на претке и (своју) најдубљу прошлост. Овиме Охрид, односно охридска прошлост, постају један од кључних архетипских представа на којима се гради македонски државотворни и национално-ослободилачки мит. 
У песми Самуилова тврдина, слично Попарсову који фигуру Самуила не гради по узору на епског ратника и освајача већ мудрог старца-жреца, и Србо Ивановски Самуилову тврђаву не представља као ратни бедем, круну државне моћи силног владара. Напротив, у песми Ивановског дата је апокалиптична слика умируће тврђаве, сабласног јутра и немирног времена које буди сени Самуилових ратника и страшним праском призива свеце у зеленим мантијама. Мотиви језовитог времена, страха, снажног праска, огња и силазак светаца са планина, подсећају на новозаветну ехсатолошку слику наговештену у Јовановом Откровену. У таквом семантичком контексту и древно Самуилово царство више подсећа на небеско, него ли на моћну освајачку државну творевину („Го љубам тоа заборавено Кралевство.“) У тој апокалиптичној слици, која имплицира идеју о очишћењу и уништењу греха, на рушевинама свега таштог и пролазног, стоји - огњени камен: „Под ребрата на каменот огнот е сочуван миг, и вишен страк израстува од пепелата на мртви копја. По та зелена врвица се јази несигурно времето, мавта со исплашени прсти, ги буди згубени сенки, но каменот го чува својот сон. Умира со својот оган." (IVANOVSKI 2016: 140) Мотив камена који се у песми доводи у везу са древним прецима чије сени и данас изазивају страх, јасно асоцира на појаву колективног, праисконског и универзалног које се кроз осећај нелагоде обзнањује и савременим генерацијама. Камен као централни мотив, јавља се у три песничке слике: као огњени камен који испод ребра носи миг (знак), као камен који чува сан, и као камен који умирући заједно са огњем нестаје. Ребро, као једина кост у људском телу која има регенеративну моћ, асоцира на природу трајности и бесконачности камена (што и јесте суштина колективно несвесног). Мотив огња у камену према Јунгу симболизује сам дух који се налази у њему. У јудеохришћанској религији је то Свети Дух, или сам Христ. „Kamen iz kojeg vrca isrka isto je tako analogan $s$ kamenim grobom ili kamenom ispred njega. U njemu je ležao Krist kao onaj tko je usnio tko je zarobljen smrću u tri dana vožnje u pakao (...) Odatle uskrsava kao novi oganj.“ (JUNG 1984: 265) У песми Ивановског огањ симболизује Самуилов дух, односно исконску повезаност са родним тлом, које васркрсава у сваком појединцу. Све је подложно пропадању, само су огањ, сан и миг, као срж људске личности, вечити. Колективно несвесно је огањ са којим камен, односно човек умиру. Миг, сан и огањ означавају архетипске обрасце грандиозних националних хероја и њихових светлих победа које у критичним моментима, сваком његовом појединцу пружају осећај снаге и вере у опстанак.

У песмама Наши фрески Милована Стефановског и Во ирквата Свети Климент Љупча Стојменског, мотив камена се јавља кроз симболе религијског система, храмове и фреске. Још у Библији камен се 
симболично везује за храм: камен као усправљени стуб (hebr. macebah ili matsebah) представља присуство самог Бога (Јован 2, 19-21); камен као симбол цркве (= Исус Христос). Јунг се посебно занимао односом религије и психоанализе. Према швајцарском психоаналитичару у архаичним митовима, бајкама, сновима, визијама, религијским системима и сл., сачувани су древни архетипски обрасци. Контакт савременог човека са њима ствара погодне услове у којима се може оживети неки од прастарих архетипова. „Што се више користимо митовима, то је већи део несвесног стављен на располагање свесном делу наше личности и тиме она постаје интегрисанија, што је један од примарних задатака психологије. На тај начин, по Јунгу, религиозност и однос према Богу могу имати значајну улогу у процесу откривања и достизања индивидуације.“ (STANOJKOVIĆ, PETROVIĆ 2010: 282) Према Јунгу у религији је садржано „prvobitno tajno značenje stečeno otkrovenjem i tajne duše su izrazile u divnim slikama. Njihovi hramovi i njihovi sveti spisi slikom i rečju obznjanjuju od davnina sveto učenje, dostupno svakoj verujućoj duši, svakom osetljivom shvatanju i svakom temeljno stečenom saznanju." (JUNG 2003: 16)

Према К. Г. Јунгу, религиозни објекти - храмови и фреске архаичним сликама, ликовима и речима, у савременом човеку могу изазвати прастаро искуство које је симболично кондензовано у њима. О значењу фресака у психоаналитичком кључу, Јунг каже:

„One su stvorene od pramaterije otkrovenja i u svakom određenom slučaju održavaju prvo iskustvo božanstva. Zato one čoveku otkrivaju uvek i naslućivanje božanskog i istovremeo obezbeđuju i od neposrednog iskustva istog. Ove slike su, zahvaljući jednoj, često stoljećima dugoj težnji ljudskog duha ugrađene $u$ jedan obuhvatni sistem misli o uređenju sveta $i \mathrm{u}$ isti mah su predstavljene jednom moćnom, raširenom, starom, prosvećenom institucijom koja je dobila ime crkva." (JUNG 2003: 17)

Јунгово тумачење фресака као система архетипских представа, готово програмски је изречено су у песми Милована Стефановског, Стари фрески:

„Старите фрески кружно наредени / само за нас чуваат свето писмо / што ни однесе и добри години / Камбаната треба да се разбере / Кога доагаат нови времиња треба љубоморно да го чуваме / коренот на кој ние израснавме. Сите стари спомени крај пепелта / го сврзуваат текот на животот / времето и бездната на просториот / А фреските кријат и нешто друго“. (STEFANOVSKI 2016: 133)

О охридским фрескама као праматеријама које савременом човеку доносе древно откровење пева и Стојменски у песми Во ирквата Свети Климент. На познату јунговску идеју о архетипским представа- 
ма асоцира већ уводна слика камена, у коме векови и боје чувају магију историје: „Далечни векови и бои / останале врз каменот да пелтекават / некакви магии на историјата“. (STOJMENSKI 2016: 119)

Разматрајући фреске на зидовима охридске светиње, песникову пажњу привлачи слика убијене и згњечене змије: „По зидишта / столбовите / и аглите / поубиено стуткани обличја на змии." (STOJMENSKI 2016: 119) У Јунговом психоаналитичком тумачењу, змија истовремено симболизује колективно несвесно и дубоку (натприродну) мудрост:

“(...) zmija potpuno odgovara nesvesnom i za osvešćivanje nesposposobnom koje, međutim, kao kolektivno nesvesno i kao instinkt, izgleda da poseduje jednu osobenu mudrost i jedno znanje koje se često oseća kao natprirodno. To je ono 'blago' koje čuva zmija (odnosno zmaj) i istovremeno razlog zašto zmija, s jedne strane, znači zlo i mrak, a s druge, međutim, mudrost. Njeno nepripadanje ičemu, hladnoća i opasnost izražavaju nagonsko koje se bezobzirno okrutno, i neumoljivo uzdiže iznad moralnih i ostalih ljudskih želja i stavova i zato deluje isto tako užasavajuće i fascinantno kao susret sa opasnom otrovnom zmijom." (JUNG 1996: 205)

У светлу Јунговог психоаналитичког тумачења змије, дијалог између лирског субјекта и фреске, симболизује процес самоспознаје, односно филозофско размишљање које води до саме суштине, до камена ( = колективно несвесно). Мудрост ирационалне и натприродне моћи предуслов је дешифровања симболичких представа на фрескама, односно архетипских слика које навиру из несвесног. На процес филозофске самоспознаје лирског „ја“, јасније указује други део песничке слике, у којој поглед (светлост) разара мрак чађавих зидова охридског храма, и свлачећи змијске коже приноси их на олтарни жртвеник тихог размишљања.

У наредној симболичкој слици, лирски субјекат је загледан у високи свод охридске цркве: „Сводот недомечтан како небо / а црн и тој црн / (можеби црн е од самоизмама) / Некои пак по него го цртале сонцето / како голем мисла на денот / кога овде зачадиле ноките.“ (STOJMENSKI 2016: 119) Наведени стихови значењски су изграђени на сукобу два основна принципа, принцип светлости (Сунце, дан) и таме (чађ), ноћи). Како у јунговској психоанализи светлост и тама увек означавају свесно и несвесно, цела песничка слика саздана је на борби између ега и колективно несвесног, између надирућих архетипских слика и цензора свесног. Мотив црних чађавих зидова охридског храма посвећеног Клименту Охридском, асоцира на познату рестаурацију цркве у 20. веку, током које су испод дебелог талога чађи пронађене средњовековне фреске, вековима скривене у мрачним наслагама. Процес стругања чађи и извирање златних површина фрескозаписа, симболично означава продирање свесног (светлог) из најдубљих, мрачних слојева несвесног. Храм посвећен 
заштитнику Охрида, Клименту Охридском, представља психу песничког „jа“, чађави мрачни зидови само су несвесно, док слика сунца кога је на мрачном своду цркве древни зограф насликао, симболизује центар и срж лирског субјекта, оно је, јунговским језиком речено, Сопство/Себство/ Личност. Према Јунгу сунце је, попут камена, симбол апсолута и савршенства личности, оно обухвата и свесно и несвесно и представља целину човекову: „Sunce je slika Božja, srce je praslika Sunca u čovjeku, kao što je zlato u zemlji, oznас̌ено i kao Deus Terrenus (...).“(JUNG 1984: 354) Сунце, Imago Deus (= човек), у нашем случају дело древног уметника, коначни је циљ филозофског проматрања субјекта, оно је пуноћа, спој свести и архетипова које је у зиду (психи) уписала рука претка (зографа). Стојменски текст финализује симболичном сликом непролазног и трајног камена који одолева свеопштој трошности и непостојаности света. Једино је камен, односно дух насељен у њему, вечан: „јужни ветрови ја одвеале / останала сал верата во овој населен камен.“ (STOJMENSKI 2016: 120) Изнад опште таштине, Стојменски издиже охридски камен у коме је урезан најдубљи миг македонског народа, а то су религија и бесмртност верујућег сабора.

Књижевни топос града Охрида у македонској поезији 20. века богатство и лепоту полисемичности остварује кроз комплексне интертекстуалне везе, при чему доминантно место заузима корпус библијске литературе. Симболична слика Охрида као божанског и сакралног града, конципирана је по узору на библијске топосе Синајске горе, Сиона и Свете Земље у којој је према религијском тумачењу Бог отпочео стварање света. Кроз сложене односе са библијском књижевношћу Охрид остварује метафорично значење отаџбине, прогоњеног али и изабраног народа који је стубове своје домовине поставио дубоко у религији и духовности.

У песничком осликавању града Охрида важно место припада симболу камена, који се појављује у разним варијететима, као Охридска тврђава, храм и сакралне фреске. Кроз многозначје мотива камена, град Охрид се појављује као архетип на коме се изграђује духовно-религијски и национално-политички идентитет модерног македонског народа. У том смислу, цар Самуил се јавља као прототип државника и ратника чије царство представља узор коме тежи македонски национ; с друге, пак, стране, Климент Охридски, представља праобразац вође, мудрог Учитеља и месије, на чијем лику почивају темељи македонског духовног континуитета. 


\section{Цитирана литература}

BIHALJI MERIN 1986: BIHALJI MERIN, Oto (ur.). Mala enciklopedija Prosveta. Četvrto izdanje. Knj. III. Beograd: Prosveta, 1986. [orig.] БИХАљИ МЕРИН, Ото (ур.). Мала енииклопедија Просвета. Четврто издање. Књ. III. Београд: Просвета, 1986.

Biblija ili Sveto pismo Staroga i Novoga zavjeta. Preveo Stari zavjet Đura Daničić, Novi zavjet preveo Vuk Stef. Karadžić. Beograd: Britansko i inostrano biblijsko društvo, 1992. [orig.] Библија или Свето писмо Старога и Новога завјета. Превео Стари завјет Ђура Даничић, Нови завјет превео Вук Стеф. Караџић. Београд: Британско и инострано библијско друштво, 1992.

ČASNI 2015: ČASNI, Danijel. „Krist kao utjelovljeni Logos“. Kairos. Knj. 9, Sv. 2 (2015): str.177-188.

DONAT 1989: DONAT, Branimir (ur.). Filozofski rječnik. Treće dopunjeno izdanje. Zagreb: Nakladni zavod Matice srpske, 1989.

ELIJADE 2003: ELIJADE, Mirča. Sveto i profano. Sremski Karlovci - Novi Sad: Izadavačka knjižarnica Zorana Stojanovića, 2003. [orig.] ЕЛИЈАДЕ, Мирча. Свето и профано. Сремски Карловци - Нови Сад: Издавачка књижарница Зорана Стојановића.

ELIJADЕ 2016: ЕЛИЈАДЕ, Mirča. Struktura simbola. <https://polja.rs/wp-content/ uploads/2016/10/Polja-152-6-9.pdf>. 12. 03. 2021.

JUNG 1984: JUNG, Karl Gustav. Psihologija i alkemija. Zagreb: Naprijed, 1984.

JUNG 1996: JUNG, Karl Gustav. Aion. Beograd: Atos, 1996.

JUNG 2003: JUNG, Karl Gustav. Arhetipovi i kolektivno nesvesno. Beograd: Atos, 2003.

KUZMAN 2010: KUZMAN, Pasko i Elizabeta DIMITROVA. Ohrid. Ohrid: Dante - Macedonia Prima, 2010. [orig.] КУЗМАН, Паско и Елизабета ДИМИТРОВА. Охрид. Охрид: Данте - Macedonia Prima, 2010.

PANOV 1985: PANOV, Branko. „Ohrid i ohridskata oblast vo prvite vekovi na slovenskata kolonizacija (VI-VIII век)“. Srednovekovna Makedonija. Tom 3. Skopje: Misla, 1985, стр. 651-658. [orig.] ПАНОВ, Бранко. „Охрид и охридската област во првите векови по словенската колонизација (VIVIII век)“. Средновековна Македонија. Од македонската средновековна историја. Том 3. Скопје: Мисла, 1985, стр. 651-658.

RAKIĆ 1991: RAKIĆ, Radomir. Biblijski rečnik. Drugo dopunjeno izdanje. Beograd: Savremena administracija, 1991. [orig.] РАКИћ, Радомир Ракић. Библијски речник. Друго допуњено издање. Београд: Савремена администрација, 1991.

STANOJKOVIĆ 2010: STANOJKOVIĆ, Nikica i Nebojša PETROVIĆ. „Pogledi na religiju u teorijama psihologa prve polovine XX veka“. Religija $i$ tolerancija. Knj. 8, sv. 14 (2010): str. 271-288. [orig.] СТАНОЈКОВИЋ, Никица и Небојша ПЕТРОВИЋ. „Погледи на религију у теоријама психолога прве половине XX века“. Религија и толеранција. Књ. 8, св. 14 (2010): стр. 271-288.

TADIĆ 1996: TADIĆ, Ivan. „Kaos, logos i suvremena kozmologija“. Crkva u svijetu. 
Knj. 31, sv. 2 (1996): str. 118-129.

TREBEŠJANIN 2006: TREBEŠJANIN, Žarko. „Arehtipovi i kolektivno nesvesno, Beograd, Atos, 2003“. Psihijatrija danas. Knj. 38, sv. 1 (2006): str. 105-107.

VUJAKLIJA 1980: VUJAKLIJA, Milan. Rečnik stranih reči i izraza. Beograd: Prosveta, 1960.

ZLATANOVIĆ 2001: ZlATANOVIĆ, Ljubiša. Jung, jastvo i individuacija. Niš: Studentski informativno-izdavački centar, 2001. [orig.] ЗЛАТАНОВИЋ, Љубиша. Јунг, јаство и индивидуащија. Ниш: Студентски информативно-издавачки центар, 2001.

\section{Извори}

PANDEV 2016: PANDEV, Dimitar i Slave Đorđo DIMOSKI. Dojdi vo Ohrid: Antologija na pesni za Ohrid. Ohrid: Grafoden, 2016. [orig.] ПАНДЕВ, Димитар и Славе Ђорђо ДИМОСКИ. Дојди во Охрид: Антологија на песни за Охрид. Охрид: Графоден, 2016. 
Milena Stankovic

\section{LIHNIDOS, A BOROUGH RADIATING ONA SUMMIT}

This is an effort to interpret basic principles and poetics of the city of Ohrid in North Macedonian poetic discourse of the 20th century. We will crossexamine Ohrid literary topos through chosen written narrative in the context of biblical symbolism, Jung archetypes, collectively unconscious thinking at the time, and through Mircea Eliade's Hierophany theory.

Keywords: Ohrid, Jung, archetype, Centre of the World, symbol, light, stone 